\title{
Evaluation of Cell Death Potential of Lepidium sativum Seed Extracts in MCF-7 Cells and Molecular Docking-based Correlation of Identified Bioactive Components with Human Caspase-6 Protein
}

\author{
Rajasekaran R, Suresh P.K* \\ Department of Biomedical Sciences, School of Biosciences and Technology, VIT, Vellore, Tamil Nadu, INDIA.
}

\begin{abstract}
Aim and Background: The methanolic extract of Lepidium sativum L. was known for its free radical scavenging potential and anticancer properties. The aim was to perform a comparative investigation of the cytotoxic and cell death potential of the Soxhlet (SOX) and crude methanolic extract (CRU). 'Materials and Methods: MTT as well as the PI-based assays in caspase-3-deficient, MCF-7 human breast cancer cells, for its cytotoxic potential and synergistic effect. LC-QTOF-MS/MS was used for characterization. These bioactive molecules were docked with human caspase-6 (2WDP) as well as its zymogen variant (4IYR) to mimicking a more physiological form of cell demise. Results: Both extracts showed a dose-dependent toxicity and the $\mathrm{IC}_{50}$ was found to be $136.75 \mu \mathrm{g} / \mathrm{ml}$, and $88.49 \mu \mathrm{g} / \mathrm{ml}$ compared with that of standard quercetin $(8.72 \mu \mathrm{g} / \mathrm{ml})$. At their $\mathrm{IC}_{50}$ concentrations, the corresponding $\mathrm{Pl}$-based flow cytometry and cell death values were $31.5 \pm 3 \%$ and $32.4 \pm 5.6$, while that of quercetin was $36.9 \pm 7.4 \%$. A synergy in cell death was seen for a combination of $L$. sativum extracts (CRU-MeOH \& SOX-MeOH) and quercetin. Thirteen (13) compounds were reported for the first time in this seed by LC-MS/MS. Good binding affinity was seen with both human caspase -6 (2WDP) and the mutated zymogen (4IYR) with reference to that of quercetin. Conclusion: This in vitro/in silico correlation showed that the methanolic extracts of $L$. sativum exhibited a significantly higher level of cell death in MCF-7 cells. Also, their synergistic increases in cell death provides a basis possibly for a combination therapy-based strategy.
\end{abstract}

Key word: Lepidium sativum L., Crude extract, LC-QTOF-MS/MS, Cell-based toxicity, Cell death potential, In-silico analysis.

\section{INTRODUCTION}

Due to their relatively lower side effects, ${ }^{1}$ plants constitute a major subset of bioactives, that can be developed for cancer treatment intheformofpurifiedcomponents;synthesized derivatives of plant-based template molecules as well as formulations consisting of concoctions and crude extracts. ${ }^{2,3}$ Among females, neoplasia of the breast is the diagnosed form of cancer that is most common, and is the first in terms of mortality statistics. ${ }^{4}$ One of the hallmark features of cancer is the development of resistance, contributing to relapse and drug failure, due to the development of recalcitrant clones. Bioprospecting for anti-cancer agents from seed sources may lead to the development of a better therapeutic strategy against breast cancer.

The seeds of $L$. sativum have been studied for their antioxidant, ${ }^{5}$ anti-inflammatory, ${ }^{6}$ anticancer ${ }^{7}$ and fracture healing properties. ${ }^{8}$ L. sativum seeds are rich in nutraceuticals including lignans, isothiocyanates, simple phenols, flavonoids, alkaloids and fatty acids. ${ }^{9} 10$ But no work has hitherto been reported that has systematically
Submission Date: 02-06-2021; Revision Date: 06-09-2021; Accepted Date: 20-10-2021.

DOI: 10.5530/ijper.56.1.19 Correspondence: Dr. Suresh P.K Department of Biomedical Sciences, School of Biosciences and Technology, VIT, Vellore, Tamil Nadu, INDIA.

Email - p.k.suresh@vit.ac.in

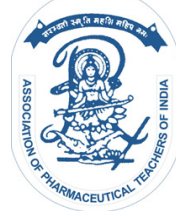

www.ijper.org 
compared the crude and Soxhlet extracts in terms of cell-based cytotoxicity and cell death. Also, there is no evidence of synergism in terms of the L. sativum seed extract- quercetin combination, as evidenced by a significant increase in cytotoxicity and cell death potential. The main aim of this study is to investigate the capabilities of L. sativum seed extracts (CRU-MeOH and SOX-MeOH) in inducing cytotoxicity in the human caspase-3 deficient, MCF-7 breast cancer cells. These extracts were characterized by LC-MS/MS. Bioactive molecules that were hitherto unreported (identification based on LC-MS/MS library-and/or literature-based comparisons) were selected for the subsequent molecular docking studies. In this in-silico analysis, human Caspase-6 (2WDP- Free human caspase-6 and 4IYR- human caspase zymogen) was chosen as the target protein (since this proteolytic enzyme is considered to be activated in cells lacking caspase-3) to provide a plausible mechanistic basis for the reported cytotoxicity and cell death data in MCF-7 cells.

\section{MATERIALS AND METHODS}

\section{Chemicals and Reagents}

Analytical grade n-hexane; ethyl acetate; methanol; HPLC grade acetonitrile; DMSO; ascorbic acid, MTT, DMEM with glucose and L-glutamine, fetal bovine serum, PBS, antibiotic-antimycotic solution, trypsin EDTA solution, sodium pyruvate solution, surfacetreated well plates and T-flasks were procured from HiMedia Laboratories Pvt. Ltd. Gallic acid, Quercetin was procured from Sigma Aldrich, India Ltd.

\section{Cell culture}

Human breast cancer line (MCF-7) was purchased from the National Centre for Cell Science (NCSS), India. Theauthentication report is provided as aSupplementary file. Briefly, the MCF-7 cells were maintained in DMEM containing 10\% (v/v) FBS; 1\% (v/v) sodium pyruvate; and $1 \%(\mathrm{v} / \mathrm{v})$ antibiotic - antimycotic solution and incubated at $5 \% \mathrm{CO}_{2}$ at $37^{\circ} \mathrm{C}$.

\section{Plant material and Extraction}

L. sativum seeds and the plant were authenticated (data attached as a supplementary file). The seeds were ground into a powder. The crude methanolic extract (CRU$\mathrm{MeOH}$ ) was prepared from $500 \mathrm{mg}$ of seed powder by using $25 \mathrm{ml}$ of $100 \% \mathrm{MeOH}$ based on a published protocol. ${ }^{11}$ The classical soxhlet extraction (SOX-MeOH) was prepared by extracting $5 \mathrm{~g}$ of seed powder with
$120 \mathrm{ml}$ of methanol based on published findings. ${ }^{12}$ Both extracts were concentrated and stored in $-20^{\circ} \mathrm{C}$.

\section{Cytotoxic potential of the methanolic Lepidium sativum L. extract in MCF-7 cell line}

The MTT-based cytotoxicity assay for the CRU-MeOH and SOX-MeOH extract was performed in MCF-7 cells and compared with that of quercetin reference molecule. This assay was based on the methods published in our previous report with slight modifications. ${ }^{13}$ Ten thousand $\left(1 \times 10^{4}\right)$ cells/well were transferred to a 96-well plate and were incubated for 1 day. Triplicate measurements were obtained to ensure reproducibility. Cells in each of the wells were then treated with varying concentrations of crude extracts $(0-1600 \mu \mathrm{g} / \mathrm{ml})$, dissolved in varying concentrations of DMSO (concentration not exceeding 1\%). The positive, vehicle and negative controls were quercetin; 1\% DMSO (v/v) in media and untreated cells respectively. After a $24-\mathrm{hr}$ incubation, treated media were discarded and five (5) $\mathrm{mg} / \mathrm{ml}$ MTT reagent was added for $4 \mathrm{hr}$ at $37^{\circ} \mathrm{C}$. This solution was removed and $200 \mu \mathrm{l}$ of DMSO was added to each well for the dissolution of the formazan crystals by gentle pipetting (5 times) and absorbance measured at $570 \mathrm{~nm}$. Cell cytotoxicity (\%) and $\mathrm{IC}_{50}$ was determined by using the following formula-

$$
\begin{aligned}
\text { Cytotoxicity } \%= & {[\text { OD }(\text { control })-\text { OD }(\text { treated }) \div \text { OD }} \\
& (\text { control })] * 100
\end{aligned}
$$

\section{Cell death potential of methanolic Lepidium sativum L. extract in MCF-7 by propidium based flow cytometry}

Flow cytometry was used to assess the cell death potential of crude methanolic and soxhleted methanolic extracts of L. sativum on MCF-7 cells. For this purpose, Propidium Iodide-based enumeration protocol of was followed with certain modifications. ${ }^{14}$ Briefly, $1.5 \times 10^{6}$ cells were grown in 6 well plates and allowed to adhere for $24 \mathrm{hr}$ and exposed to the various concentrations of seed extracts for a 24-hr time period along with suitable controls. Treated cells were dislodged by trypsinization and washed three times with PBS. The cell pellet were suspended in $400 \mu \mathrm{l}$ of PBS and stored in an ice bath. The cell supernatants were then treated with RNase $(200 \mu \mathrm{g} / \mathrm{ml})$ solution and stained with propidium iodide $(50 \mu \mathrm{g} / \mathrm{ml})$ for $30 \mathrm{~min}$ in an ice bath (in the dark). The unstained and the PI-stained cells (untreated) will be used as controls. The sample was analyzed by flow cytometry using a (Beckman Coulter, USA). Ten 
thousand (10,000 cells)/ sample were collected and the histograms analysed using Cytotec software.

\section{Synergistic effect of Lepidium sativum L. extracts using MTT and flow cytometry}

To investigate the synergistic effect, two different types of methanolic extracts of $L$. sativum seeds extracts were each combined with quercetin (reference molecule). The combination based on the respective $\mathrm{IC}_{50}$ values for each of the CRU $\mathrm{MeOH}$ and $\mathrm{SOX} \mathrm{MeOH}$ combined separately with the 50\% inhibitory value for quercetin. The alterations in the cell death potential in MCF-7 cells were evaluated. This evaluation was based on the MTT assay as well as with the flow cytometry-based enumeration of live and dead cells following staining with Propidium Iodide (PI) as mentioned above ${ }^{13-15}$

\section{LC-MS/MS analysis of the Lepidium sativum L. seed extract}

The bioactive profiling of $L$. sativum crude and soxhleted methanol extract was done by LC-Q-TOF-MS/MS. ${ }^{10}$ This profiling was outsourced and performed in the Instrumentation facility in IISc, Bangalore. Details with regards to the methodology were provided by them and is briefly described in the supplementary files. The concentrated L. sativum crude (CRU-MeOH), as well as the soxhleted methanolic extracts (SOX$\mathrm{MeOH}$ ), were dissolved in HPLC grade methanol and run through a $0.22 \mu \mathrm{m}$ syringe filter. Analysis was done in the Impact HD (Bruker) ESI QTOF high-resolution mass spectrometer. The CRU-MEOH and SOX-MeOH were analyzed in both the positive and negative ion. The obtained $\mathrm{m} / \mathrm{z}$ was analysed using the Bruker Compass Data Analysis 4.2 software and compared with published data generated from the same sample under similar instrumentation conditions.

In silico analysis of Lepidium sativum L. seed compounds against apoptotic protein human caspase-6

The hitherto unidentified compounds, from the LC-MS/MS spectra generated from the CRU-MeOH and SOX-MeOH extracts, were docked. The X-ray crystallized structure of human caspase 6 (PDB ID: 2WDP and 4IYR) was downloaded from the Protein Data Bank (PDB). 3D structures of $L$ sativum compounds were fetched from CORINA. Molecular docking using AUTODOCK 4.0, was performed using standard protocols. ${ }^{16}$ Kollman charges, solvation parameters; addition of polar hydrogens and the assignment of Gasteiger charges were done to the target, human caspase-6 protein. The ligands and proteins were optimized using Auto dock tools. Ten (10) conformers were generated for each ligand using the Lamarckian Genetic Algorithm (LGA) and analysed based on the binding energy. The LigPlot and PyMol was used for Protein-Ligand interaction studies.

\section{RESULTS}

\section{Cytotoxicity of Lepidium sativum L. in MCF-7 cell line}

To evaluate the relative cytotoxic potential of our crude extracts, the widely accepted MTT assay was performed on the ER +ve MCF-7 luminal epithelial breast cancer cell line. This data set was compared with the results obtained for quercetin (positive control). Our results indicate that the mean $\mathrm{IC}_{50}$ value (based on three independent experiments -each experiment performed in quadruplicate) of CRU MeOH and SOX-MeOH was $88.49 \mu \mathrm{g} / \mathrm{ml}$, and $136.75 \mu \mathrm{g} / \mathrm{ml}$ respectively (Figure 1). The positive control quercetin exhibited an $\mathrm{IC}_{50}$ value of $8.72 \mu \mathrm{g} / \mathrm{ml}$ (See Supplementary information).

\section{Cell death potential of Lepidium sativum L. seed extract using flow cytometry}

The fluorochrome (PI) that is capable of labelling DNA allows for a quick and accurate flow cytometry-based assessment of DNA content in the cells, and hence

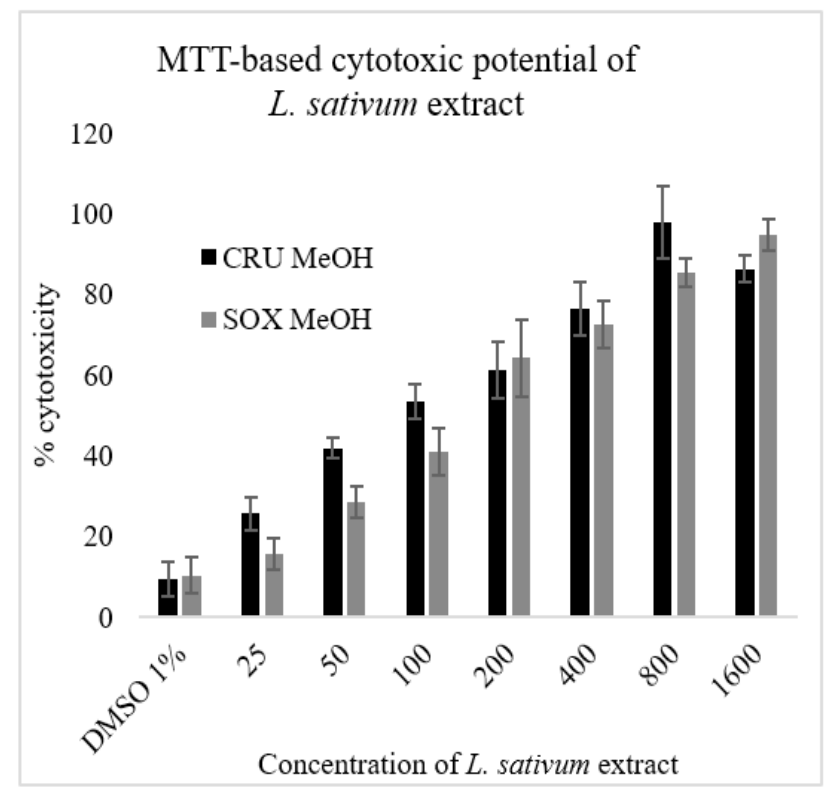

Figure 1: Cytotoxic potential of Lepidium sativum L. seed extracts on MCF-7 cell by MTT assay. Cells were treated with different drug for $24 \mathrm{hr}$ and cytotoxicity was measured with MTT assay. All data were expressed in $\mathrm{N}=3$ (quadruplicate) Mean \pm SD, $p$ value calculated using one-way ANOVA. IC $_{50} \mathrm{CRU}-\mathrm{MeOH}$ is $88.49 \mu \mathrm{g} / \mathrm{ml}(p<0.05)$ and $\mathrm{SOX}-\mathrm{MeOH}$ is $136.75 \mu \mathrm{g} / \mathrm{ml}(p<0.02)$. 
the cell death potential. Both CRU-MEOH and SOX$\mathrm{MeOH}$ treatment-induced cell death dose-dependently, when compared with control (untreated cells) as shown in (Figure 2). At the $\mathrm{IC}_{50}$ value, (selected based on the MTT results) quercetin $(8.72 \mu \mathrm{g} / \mathrm{ml})$ showed $36.9 \pm 7.4$ $\%$ PI-stained dead cells. The CRU-MeOH extract $(45,89,134 \mu \mathrm{g} / \mathrm{ml})$ showed respectively $26.9 \pm 0.9$, $31.5 \pm 3.3,42.1 \pm 2.0 \%$ of PI-stained dead cells. The SOX$\mathrm{MeOH}$ extract $(69,137,206 \mu \mathrm{g} / \mathrm{ml})$ respectively showed $32.4 \pm 5.1,32.4 \pm 5.6,38.2 \pm 1.0$ of PI-stained dead cells.

\section{Synergistic of Lepidium sativum L. seed extracts combined with standard quercetin}

Our $L$ sativum seed extracts, in combination with quercetin, showed a synergistic effect in the MCF-7 cell line. In the MTT-based experiment; the combination of (Que + CRU-MeOH) showed 100\% cytotoxicity in the MCF-7 cells. Under identical experimental conditions (Que + SOX-MeOH) exhibited a $91.9 \pm 13.78 \%$ cytotoxicity in the same MCF-7 breast cancer cell line (see Figure. 3A). In the PI-based flow cytometry experiment; the combination of (Que + CRU-MeOH) (mixed at their respective $\mathrm{IC}_{50}$ concentrations) showed $55.45 \pm 9.3$ cell death in MCF-7 cells. Similarly, the combination of Que + SOX-MeOH, at their $\mathrm{IC}_{50}$ values, showed $61.92 \pm 5.37$ in the MCF-7 cells (Figure 3B). This data set provided strong evidence of synergism of $L$. sativum seed extracts with quercetin.

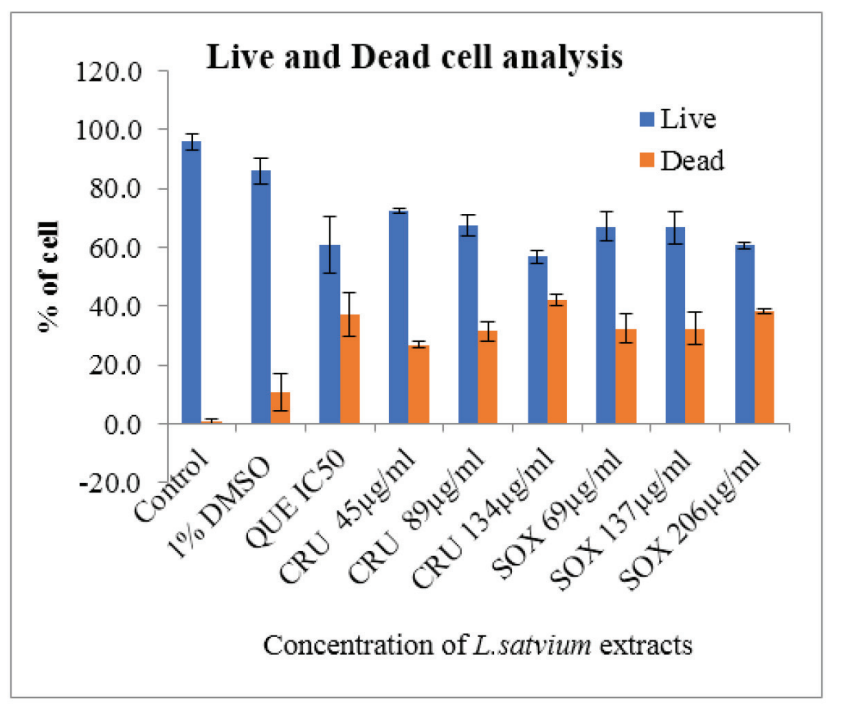

Figure 2: Live and dead cell analysis of $L$. sativum seed extracts compared with control and standard drug using PI-based flow cytometry. \% of Live and dead cells of MCF-7 cells against $L$. sativum crude extracts. All data expressed in 3 independent experiments $n=3$, Mean \pm SD.
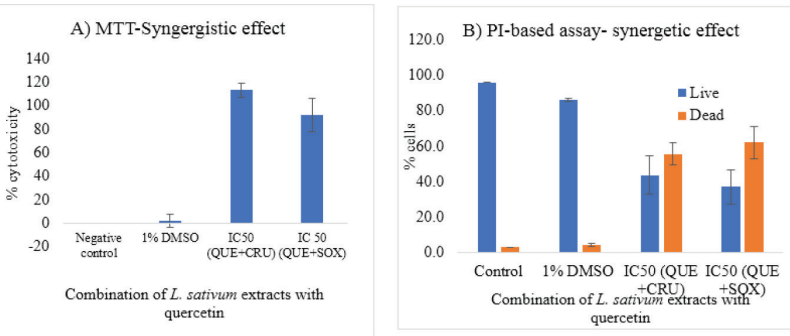

Figure 3: Synergistic effect of Lepidium sativum seed extracts combined with standard quercetin. 3A. MTT based synergistic effect-Cells were treated with combination of $L$. sativum seed extract with parental compound quercetin for $24 \mathrm{hr}$ and cytotoxicity was measured with MTT assay. All data were expressed in $\mathrm{N}=3$ (quadruplicate) Mean $\pm \mathrm{SD}$. 3B. PI-based cell death analysis of combination treatment of $L$. sativum seed extracts with parental compound. \% of Live and dead cells of MCF-7 cells against L.sativum crude extracts. All data expressed in 3 independent experiments $n=3$, Mean $\pm S D$.

\section{LC-MS/MS analysis of the two different types of methanolic Lepidium sativum L. seed extracts}

Liquid chromatography, with ESI-ionization mode highresolution quadrupole time-of-flight mass spectrometer (Q-TOF-MS), is highly sensitive and selective due to its quick metabolite analysis with precise separation of the different peaks. The ionization of compounds led to the generation of charged and fragmented molecules and identified based on their $m / z$ value. The major peak of standard quercetin had a peak Rt of $20.2 \mathrm{~min}$ and an $\mathrm{m} / \mathrm{z}$ value of $-302.04[\mathrm{M}+\mathrm{H}]^{+}$(negative ion mode). Twenty compounds were detected. Among these, 13 compounds were the first to be reported in L. sativum (CRU-MeOH \& SOX-MeOH) in the positive and in the negative ion mode (Table 1). The other compounds and structures were elucidated (See Supplementary information).

In-silico binding analysis of Lepidium sativum L. compounds free human caspase- 6 (2WDP) and Human caspase- 6 zymogen (4IYR)

Molecular docking for the 13 compounds identified (and hitherto unreported) from L. sativum crude extracts were performed on the human caspase 6 protein (2WDP and 4IYR) along with standard quercetin (Table 2). Lower (more negative) the binding energy, higher the affinity of the interaction between the target protein and the ligands. In Autodock 4.2, standard quercetin shows a binding energy of -6.27 and -6.0 $\mathrm{KcalMol}^{-1}$ for the two druggable targets -2WDP and 4IYR respectively. The compound (identified from the crude extract) (2R)-2-[3-[(E)-3-(3-nitrophenyl)-3-oxoprop-1-enyl] phenoxy] propanoate showed the lowest 


\begin{tabular}{|c|c|c|c|c|c|c|}
\hline SI.No & Code & RT-min & Compound Detected & $\begin{array}{c}{[\mathrm{M}+\mathrm{H}]+/} \\
{[\mathrm{M}+\mathrm{X}]+}\end{array}$ & Class & $\begin{array}{l}\text { Reported } \\
\text { biological } \\
\text { activity }\end{array}$ \\
\hline 1 & $\mathrm{C} 1^{*}$ & 14.5 & $\begin{array}{l}\text { (2R)-2-[3-[(E)-3-(3-nitrophenyl)-3-oxo-prop-1- } \\
\text { enyl]phenoxy]propanoate }\end{array}$ & 339.08 & $\begin{array}{l}\text { Coumarin Chalcone } \\
\text { fibrates }\end{array}$ & $\begin{array}{l}\text { Anti-dyslipidemic } \\
\text { effects }^{21}\end{array}$ \\
\hline 2 & $\mathrm{C} 2$ & 2.9 & $\begin{array}{l}\text { dimethyl (E)-2-[dibutoxy(oxido) } \\
\text { phosphaniumyl]but-2-enedioate }\end{array}$ & 337.14 & $\begin{array}{l}\text { Dimethyl fumarate } \\
\text { derivative }\end{array}$ & Anticancer ${ }^{22}$ \\
\hline 3 & C3 & 6.7 & $\begin{array}{l}\mathrm{N} \text {-[[1-(4-methoxyphenyl)pyrazol-3-yl]methyl]- } \\
\text { 2-thiomorpholin-3-yl-acetamide }\end{array}$ & 347.15 & Pyrazol Alkaloids & Anticancer ${ }^{23}$ \\
\hline 4 & $\mathrm{C} 4$ & 9.7 & Citrinin & 251.09 & Polyketide & Anticancer ${ }^{24}$ \\
\hline 5 & C5 & 9.6 & $\begin{array}{c}\text { (4aR,7aS)-4-(5-fluoropyrimidin- } \\
\text { 2-yl)-N-isopropyl-2,3,4a,5,7,7a- } \\
\text { hexahydropyrrolo[3,4-b][1,4]oxazine-6- } \\
\text { carboxamide }\end{array}$ & 310.17 & Oxazine & Anticancer ${ }^{25}$ \\
\hline 6 & C6 & 12.5 & $\begin{array}{c}\text { (1S,3S)-3-acetyl-1-[(2R,4R,5S,6S)-4-amino- } \\
\text { 5-hydroxy-6-methyl-tetrahydropyran-2-yl]oxy- } \\
\text { 3,6,11-trihydroxy-10-methoxy-2,4,7,8,9,10- } \\
\text { hexahydro-1H-tetracene-5,12-dione }\end{array}$ & 532.22 & $\begin{array}{l}\text { ND- Closely related } \\
\text { to doxorubicin }\end{array}$ & Anticancer ${ }^{26}$ \\
\hline 7 & $\mathrm{C} 7$ & 5.4 & $\begin{array}{l}\mathrm{N} \text {-(p-tolyl)-2-[4-(2-thienyl)-6-(trifluoromethyl) } \\
\text { pyrimidin-2-yl]sulfanyl-acetamide }\end{array}$ & 408.05 & Pyrimidine alkaloids & Anticancer ${ }^{27}$ \\
\hline 8 & C8 & 10.3 & $\begin{array}{l}\text { 1-deoxy-1-[(5-nitro-2,6-dioxo-1,2,3,6- } \\
\text { tetrahydropyrimidin-4-yl)amino]-D-ribitol }\end{array}$ & 305.07 & Glycoside & ND \\
\hline 9 & $\mathrm{~S} 1$ & 4.0 & $\begin{array}{l}\text { 3-[2-(propanoylamino)ethylsulfanyl]-N- } \\
\text { [(3S,5S)-2,4,5-trihydroxy-6-(hydroxymethyl) } \\
\text { tetrahydropyran-3-yl]propanamide }\end{array}$ & 367.15 & Glucosamine & ND \\
\hline 10 & S2 & 7.8 & $\begin{array}{c}\mathrm{N} \text {-cyclopropyl-6-[[3-(5-fluoro-2-piperidyl) } \\
\text { isoxazol-4-yl]methoxy]pyridine-3- } \\
\text { carboxamide }\end{array}$ & 361.17 & $\begin{array}{l}\text { Pyridine Alkaloids/ } \\
\text { Isoxazole derivative }\end{array}$ & Anticancer ${ }^{28}$ \\
\hline 11 & S3 & 12.0 & TMC-135A & 720.33 & Ansamycis & Anticancer ${ }^{29}$ \\
\hline 12 & S4 & 5.6 & $\begin{array}{l}\text { 4-amino-N-benzyl-2-thioxo-3-[3- } \\
\text { (trifluoromethyl)phenyl]thiazole-5- } \\
\text { carboxamide }\end{array}$ & 408.05 & Thiazole thione & Anticancer ${ }^{30}$ \\
\hline 13 & S5 & 51.0 & 13-cyclopent-2-en-1-yltridec-6-enoic acid & 277.22 & Gorlic acid-FA & ND \\
\hline
\end{tabular}

* represents the compounds present in both $\mathrm{CRU}-\mathrm{MeOH}$ and SOX-MeOH, $\mathrm{C}_{1}-\mathrm{C}_{8}$-compounds present in $\mathrm{CRU}-\mathrm{MeOH}$ extract, $\mathrm{S}_{1}-\mathrm{S}_{5}$ - compounds present in $\mathrm{SOX}_{-} \mathrm{MeOH}$ extract, ND-Not Determined, FA-Fatty acid.

binding energy of $-7.81 \mathrm{KcalMol}^{-1}$ in 2WDP. However, in the case of 4IYR, N-[[1-(4-methoxyphenyl) pyrazol3-yl] methyl]-2-thiomorpholin-3-yl-acetamide (identified from the crude extract) showed the lowest binding energy of $-9.09 \mathrm{KcalMol}^{-1}$.

\section{DISCUSSION}

Cell death induction in 2D breast cancer model systems by natural extract-based bioactive components would be the POC approach to overcome resistance mechanisms (one of the cardinal hallmark features of cancer). Our overall objectives were to demonstrate increased cell death induction potential of the methanolic extracts of L. sativum in MCF-7 cells, using MTT assay-based cytotoxicity and flow cytometry-based enumeration of non-viable PI-treated cells. In addition, we have certain probable contributors to this form of cell demise. In MTT, our concentration-dependent reproducible results with the positive control (See supplementary information) enabled us to validate our methodology and are in concordance with published findings ${ }^{17}$ as well as determine the relative potency of the extract in our model system. To the best of our knowledge, our demonstration of $L$. sativum methanolic extracts (CRU-MeOH and SOX-MeOH)-mediated increments in cell death is the first of its kind in terms of specifically determining its relative MTT-based cytotoxic potential (Figure 1) correlated with PI-mediated, flow cytometrybased cell death assays in MCF-7 cells (Figure 2). Previous studies have shown that that $L$. sativum extracts can induce cytotoxicity in the MCF-7, ${ }^{7}$ Jurkat E6-1 cells ${ }^{18}$ and HepG $2^{19}$ cells, following treatment over a $24-48 \mathrm{hr}$ time period. Our MTT data and flow cytometry data 


\begin{tabular}{|c|c|c|c|c|c|c|c|c|}
\hline SI.No & $\begin{array}{c}\text { Cmp. } \\
\text { ID }\end{array}$ & $\begin{array}{l}\text { Merged Non- } \\
\text { polar atoms }\end{array}$ & $\begin{array}{c}\text { Aromatic } \\
\text { carbons }\end{array}$ & $\begin{array}{c}\text { Rotatable } \\
\text { bonds }\end{array}$ & $\begin{array}{c}\text { 2WDP } \\
\text { (Kcal/Mol) }\end{array}$ & Amnio acid -2WDP & $\begin{array}{c}\text { 4IYR } \\
\text { (Kcal/Mol) }\end{array}$ & Amnio acid -4IYR \\
\hline 1 & QUE & 5 & 15 & 6 & -6.2 & Lys133, Val212 & -6 & His168, Glu191 \\
\hline 2 & $\mathrm{C} 1 * \%$ & 14 & 12 & 7 & -7.81 & $\begin{array}{l}\text { Thr60, Arg220, } \\
\text { Arg259 }\end{array}$ & -7.47 & $\begin{array}{l}\text { His168, Asn169, } \\
\text { Ser268 }\end{array}$ \\
\hline 3 & $\mathrm{C} 2 \%$ & 25 & Nil & 13 & -2.96 & His58 & -4.04 & His168, Asp193 \\
\hline 4 & $\mathrm{C} 3+\%$ & 20 & 9 & 6 & -6.16 & His219 & -9.09 & Ser268, Val192 \\
\hline 5 & $\mathrm{C} 4 \%$ & 12 & 6 & 3 & -4.64 & Trp227, Arg259 & -5.48 & Ala194 \\
\hline 6 & C5 & 19 & 4 & 4 & -4.63 & Nil & -6.14 & Nil \\
\hline 7 & C6 & 27 & 10 & 9 & -6.37 & Glu123, Gly165 & -6.11 & Gln167 \\
\hline 8 & $\mathrm{C} 7$ & 13 & 14 & 7 & -5.17 & Nil & -7.06 & Nil \\
\hline 9 & C8\% & 7 & 4 & 11 & -4.14 & Glu63, Asn125 & -4.16 & $\begin{array}{l}\text { His168, Asp193, } \\
\text { Thr190, Ser268 }\end{array}$ \\
\hline 10 & S1※ & 20 & Nil & 15 & -2.95 & Ser218 & -3.89 & $\begin{array}{c}\text { His168, Asp169, } \\
\text { Glu191 }\end{array}$ \\
\hline 11 & $\mathrm{~S} 2$ & 19 & 11 & 7 & -6.17 & Nil & -7.81 & Ser268 \\
\hline 12 & S3 & 44 & 9 & 9 & -3.83 & Nil & -6.13 & Nil \\
\hline 13 & S4 & 11 & 15 & 7 & -4.65 & Thr60, Glu123 & -6.97 & Nil \\
\hline 14 & S5 & 29 & Nil & 13 & -5.89 & Nil & -5.55 & Nil \\
\hline
\end{tabular}

ND- Not able to perform the autodock, * -compound with the highest binding affinity in 2WDP, †- a compound with the highest binding affinity in 4 IYR * Compounds which bind in active sites of 2 WDP and 4 IYR.

suggest that CRU-MeOH and SOX-MeOH extract have produced a statistically significant increase in cytotoxicity in the MCF-7 cell line at concentrations of $88.49 \mu \mathrm{g} / \mathrm{ml}$, and $136.75 \mu \mathrm{g} / \mathrm{ml}$ respectively in comparison with that of the negative and vehicle controls. In our present study, we also investigated the combination therapy strategy by combining the two L. sativum crude extracts $\left(\mathrm{IC}_{50}\right)$ with quercetin $\left(\mathrm{IC}_{50}\right)$ a natural molecule with very good antineoplastic potential. In the MTT and PI based flow cytometry, these combinations showed a significant increase in cell death than when they were treated singly (Figure 3A and Figure 3B). It has been shown that doxorubicin, in combination with the hydroalcoholic extract of Blepharis persica seed extract, increased the cytotoxicity in HT-29 cancer cell line in comparison with control data. ${ }^{15}$ A study showed that a combination of GSPs and RES caused a synergistic effect in human MCF-7 cells that are ER-positive and in ER-negative MDA-MB-231 breast cancer cells. ${ }^{20}$ Previous literature on other natural molecules from varied seed sources served to corroborate our combination treatment-based findings in terms of increasing cytotoxicity and cell death. Also, our positive results served to validate our POC strategy for the development of anti-breast cancer formulations from natural sources.
Only a few studies have been reported on the chemical composition of $L$. sativum extracts based on liquid chromatography-coupled with mass spectrometry. ${ }^{10,18}$ Our study is first of its kind in terms of the comparative profiling of bioactive compounds in CRU-MeOH and SOX MeOH extracts respectively using LC-ESIQTOF-MS/MS (under our defined extraction and analysis conditions). These identified compounds shown some biological activity on the different cancer cell lines based on data reported by others (discussed in Table 1) These bioactive compounds might plausibly activate the apoptotic pathways, thereby contributing to increases in cell death in the MCF-7 cell line. To corroborate our in vitro findings, the in-silico dockingbased approach provides additional information about the possible nature and site of interaction of certain selected $L$. sativum bioactive molecules with human caspase-6. This protein was selected, since our MCF-7 cell line lacks human caspase-3. ${ }^{31,32}$ In the case of both proteins, the L. sativum ligands showed good binding energy when compared with that of standard quercetin (Table 2). It is possible that the interaction of ligand at the binding site induced a conformational change and an induced-fit model may be used to explain this interaction. ${ }^{33,34}$ This conformational change allows for the initial caspase-6 activation. ${ }^{35,36}$ Preliminary in-silico 
studies suggest that the identified compounds of L. sativum seed may cause cell death by the induction of the human caspase-6 pathway. Further experiments in MCF-7 cells will serve to confirm our in-silico findings.

\section{CONCLUSION}

Our findings suggest that the methanolic extract of the seeds of $L$ sativum exhibited a dose-dependent cytotoxic effect in the human breast cancer MCF-7 cell line, that is caspase-3 deficient. PI-based enumeration of apoptotic cells, using the flow cytometer, provides a probable mode of cell death of the two different types of methanolic extracts of the seeds of $L$ sativum (singly and/or in combination with quercetin). Interpretation of the LC-MS/MS spectra showed the presence of bioactive compounds with plausible cell death/anti-neoplastic potential. In silico data suggest that some of the identified bioactive principles in the two types of methanolic extracts of $L$ sativum seeds exhibited significant binding affinity to human caspase-6 (in comparison with that of Quercetin). This in silico data provides us with some evidence of the probable involvement of this enzyme (directly or indirectly) in the extract-induced cell death phenomena. Further, this result provides us with an impetus to validate the specific involvement of human caspase-6 in in vitro and in vivo xenograft model systems, involving MCF-7 cells.

\section{ACKNOWLEDGEMENT}

The authors acknowledge the infrastructural support and constant encouragement provided by the management of VIT, Vellore. We also thank DST (SERB) for funding a project on drug delivery systems ((SB/SO/HS-157 (2013)), to the corresponding author, and for creating the scientific ambience. We thank the LC-MS facility, IISC, Bangalore for the LC-MS/MS analysis outsourced to them.

\section{CONFLICT OF INTEREST}

The authors declare no conflict of interest.

\section{Funding}

This work was supported, in part, by the Vellore Institute of Technology. Also, Council of Scientific and Industrial Research (CSIR), New Delhi, has provided additional financial support in the form of a Senior Research Fellowship (09/844(0075)/2019-EMR 1) to the lead author.

\section{ABBREVIATIONS}

CRU-MeOH: Simple crude methanolic extract, SOX-MeOH: Soxhlet methanolic extract; MTT: 3-(4,5-dimethylthiazol-2-yl)-2,5-diphenyltetrazolium; PI: Propidium Iodide; FBS: Fetal Bovine Serum; LC-ESI-QTOF-MS/MS: High-performance liquid chromatography coupled with electrospray ionizationquadrupole-time of flight-mass spectrometry; DMEM: Dulbecco's Modified Eagle’s medium.

\section{REFERENCES}

1. Koparde AA, Doijad RC, Magdum CS. Natural products in drug discovery. Pharmacognosy-medicinal plants. 2019:1-20.

2. Bishayee A, Sethi G. Bioactive natural products in cancer prevention and therapy: progress and promise. Semin Cancer Biol. 2016;40-41:1-3. doi: 10.1016/j.semcancer.2016.08.006, PMID 27565447.

3. Thomford NE, Senthebane DA, Rowe A, Munro D, Seele P, Maroyi A, et al. Natural products for drug discovery in the 21st century: innovations for novel drug discovery. Int J Mol Sci. 2018;19(6):1578. doi: 10.3390/ijms19061578, PMID 29799486.

4. Bray F, Ferlay J, Soerjomataram I, Siegel RL, Torre LA, Jemal A. Global cancer statistics 2018: GLOBOCAN estimates of incidence and mortality worldwide for 36 cancers in 185 countries. CA Cancer J Clin. 2018;68(6):394-424. doi: 10.3322/caac.21492, PMID 30207593.

5. Malar J, Chairman K, Singh AR, Vanmathi JS, Balasubramanian A, Vasanthi K. Antioxidative activity of different parts of the plant Lepidium sativum Linn. Biotechnol Rep. 2014; 3: 95-8.

6. Alqahtani FY, Aleanizy FS, Mahmoud AZ, Farshori NN, Alfaraj R, Al-Sheddi ES, et al. Chemical composition and antimicrobial, antioxidant, and anti-inflammatory activities of Lepidium sativum seed oil. Saudi J Biol Sci. 2019;26(5):1089-92. doi: 10.1016/j.sjbs.2018.05.007, PMID 31303845.

7. Mahassni SH, Al-Reemi RM. Apoptosis and necrosis of human breast cancer cells by an aqueous extract of garden cress (Lepidium sativum) seeds. Saudi J Biol Sci. 2013;20(2):131-9. doi: 10.1016/j.sjbs.2012.12.002, PMID 23961228.

8. Yadav YC, Jain A, Srivastava DN, Jain A. Fracture healing activity of ethanolic extract of Lepidium sativum L. seeds in internally fixed rats' femoral osteotomy model. Int J Pharm Pharm Sci. 2011;3(2):193-7.

9. Zia-Ul-Haq M, Ahmad S, Calani L, Mazzeo T, Del Rio D, Pellegrini N, et al. Compositional study and antioxidant potential of Ipomoea hederacea Jacq. and Lepidium sativum L. seeds. Molecules. 2012;17(9):10306-21. doi: 10.3390/molecules170910306, PMID 22932212.

10. Kadam D, Palamthodi S, Lele SS. LC-ESI-Q-TOF-MS/MS profiling and antioxidant activity of phenolics from L. Sativum seed cake. J Food Sci Technol. 2018;55(3):1154-63. doi: 10.1007/s13197-017-3031-8, PMID 29487458.

11. Rispail N, Morris P, Webb KJ. Phenolic compounds: extraction and analysis. In Lotus japonicus handbook. Berlin: Springer; 2005. p. 349-54.

12. Naveen Kumar DR, George VC, Suresh PK, Kumar RA. Acceleration of pro-caspase-3 maturation and cell migration inhibition in human breast cancer cells by phytoconstituents of Rheum emodi rhizome extracts. Excli J. 2013;12:462-78. PMID 26417238.

13. Sinha A, P K S. Enhanced Induction of Apoptosis in HaCaT Cells by Luteolin Encapsulated in PEGylated Liposomes-Role of Caspase-3/Caspase-14. Appl Biochem Biotechnol. 2019;188(1):147-64. doi: 10.1007/s12010-0182907-z, PMID 30390204.

14. Schmid I, Ferbas J, Uittenbogaart CH, Giorgi JV. Flow cytometric analysis of live cell proliferation and phenotype in populations with low viability. Cytometry. 1999;35(1):64-74. doi: 10.1002/(sici)1097-0320(19990101)35:1<64::aidcyto9>3.3.co;2-p, PMID 10554182.

15. Aghaabbasi K, Askari N, Hassani Kumleh HH, Torkzadeh-Mahani M, Ramzani-Ghara A. The Blepharis persica seed hydroalcoholic extract synergistically enhances the apoptotic effect of doxorubicin in human colon 
cancer and gastric cancer cells. Mol Biol Rep. 2020;47(2):843-53. doi: 10.1007/s11033-019-04711-z, PMID 31848915.

16. Morris GM, Huey R, Lindstrom W, Sanner MF, Belew RK, Goodsell DS, et al. AutoDock4 and AutoDockTools4: automated docking with selective receptor flexibility. J Comput Chem. 2009;30(16):2785-91. doi: 10.1002/jcc.21256, PMID 19399780.

17. Duo J, Ying GG, Wang GW, Zhang L. Quercetin inhibits human breast cancer cell proliferation and induces apoptosis via $\mathrm{Bcl}-2$ and Bax regulation. Mol Med Rep. 2012;5(6):1453-6. doi: 10.3892/mmr.2012.845, PMID 22447039.

18. Basaiyye SS, Kashyap S, Krishnamurthi K, Sivanesan S. Induction of apoptosis in leukemic cells by the alkaloid extract of garden cress (Lepidium sativum L.). J Integr Med. 2019;17(3):221-8. doi: 10.1016/j.joim.2019.03.004, PMID 30940420.

19. Ait-Yahia O, Bouzroura SA, Belkebir A, Kaci S, Aouichat AB. Cytotoxic activity of flavonoid extracts from Lepidium sativum (Brassicaceae) seeds and leaves. Int J Pharmacogn Phytochem Res. 2015;7(6):1231-5.

20. Gao Y, Tollefsbol TO. Combinational proanthocyanidins and resveratrol synergistically inhibit human breast cancer cells and impact epigeneticmediating machinery. Int J Mol Sci. 2018;19(8):2204. doi: 10.3390/ ijms19082204.

21. Sashidhara KV, Dodda RP, Sonkar R, Palnati GR, Bhatia G. Design and synthesis of novel indole-chalcone fibrates as lipid lowering agents. Eur J Med Chem. 2014;81:499-509. doi: 10.1016/j.ejmech.2014.04.085, PMID 24871900.

22. Linker RA, Haghikia A. Dimethyl fumarate in multiple sclerosis: Latest developments, evidence and place in therapy. Ther Adv Chronic Dis. 2016;7(4):198-207. doi: 10.1177/2040622316653307, PMID 27433310.

23. Battula KS, Narsimha S, Thatipamula RK, Reddy YN, Nagavelli VR. Synthesis and biological evaluation of novel thiomorpholine 1,1-dioxide derived 1 , 2, 3-triazole hybrids as potential anticancer agents. ChemistrySelect. 2017;2(14):4001-5. doi: 10.1002/slct.201700524.

24. de Oliveira Filho JWG, Islam MT, Ali ES, Uddin SJ, Santos JVO, De Alencar MVOB, et al. A comprehensive review on biological properties of citrinin. Food Chem Toxicol. 2017;110:130-41. doi: 10.1016/j.fct.2017.10.002, PMID 28993214.

25. Zinad DS, Mahal A, Mohapatra RK, Sarangi AK, Pratama MRF. Medicinal chemistry of oxazines as promising agents in drug discovery. Chem Biol Drug Des. 2020;95(1):16-47. doi: 10.1111/cbdd.13633, PMID 31583840.

26. Suchaichit N, Kanokmedhakul K, Panthama N, Poopasit K, Moosophon P, Kanokmedhakul S. A $2 \mathrm{H}$-tetrahydropyran derivative and bioactive constituents from the bark of Goniothalamus elegants Ast. Fitoterapia. 2015;103:206-12. doi: 10.1016/j.fitote.2015.04.005, PMID 25865074.

27. Yang L, Ma X, Yuan C, He Y, Li L, Fang S, et al. Discovery of 2-((4, 6-dimethylpyrimidin-2-yl) thio)-N-phenylacetamide derivatives as new potent and selective human sirtuin 2 inhibitors. Eur J Med Chem. 2017;134:230-41. doi: 10.1016/j.ejmech.2017.04.010, PMID 28415012.

28. Sharath Chandra SP, Mahadimane PV. In vivo evaluation of anticancer activity of Novel 6-Fluoro-3- (Piperidin-4-YI) benzo [D] isoxazole. Int J Bioassays. 2014;3(12):3569-73.

29. Kohno JU, Nishio M, Kawano K, Nakanishi N, Suzuki SI, Uchida T, et al. TMC-1 A, B, C and D, new antibiotics of the manumycin group produced by Streptomyces sp. Taxonomy, production, isolation, physico-chemical properties, structure elucidation and biological properties. J Antibiot. 1996;49(12):1212-20. doi: 10.7164/antibiotics.49.1212.

30. Ansari M, Shokrzadeh M, Karima S, Rajaei S, Fallah M, Ghassemi-Barghi N, et al. New thiazole-2 (3H)-thiones containing 4-(3, 4, 5-trimethoxyphenyl) moiety as anticancer agents. Eur J Med Chem. 2020;185:111784. doi: 10.1016/j.ejmech.2019.111784.

31. Baumgartner R, Meder G, Briand C, Decock A, D'arcy A, Hassiepen U, et al. The crystal structure of caspase-6, a selective effector of axonal degeneration. Biochem J. 2009;423(3):429-39. doi: 10.1042/BJ20090540, PMID 19694615.

32. Slee EA, Adrain C, Martin SJ. Executioner caspase-3, -6, and -7 perform distinct, non-redundant roles during the demolition phase of apoptosis. J Biol Chem. 2001;276(10):7320-6. doi: 10.1074/jbc.M008363200. PMID 11058599.

33. Bernetti M, Cavalli A, Mollica L. Protein-ligand (un) binding kinetics as a new paradigm for drug discovery at the crossroad between experiments and modelling. Med. Chem Commun. 2017;8(3):534-50.

34. Pang $\mathrm{X}$, Zhou HX. Rate constants and mechanisms of protein-ligand binding. Annu Rev Biophys. 2017;46:105-30. doi: 10.1146/annurevbiophys-070816-033639, PMID 28375732.

35. Edgington LE, Van Raam BJ, Verdoes M, Wierschem C, Salvesen GS, Bogyo M. An optimized activity-based probe for the study of caspase- 6 activation. Chem Biol. 2012;19(3):340-52. doi: 10.1016/j.chembiol.2011.12.021, PMID 22444589.

36. Vaidya S, Velázquez-Delgado EM, Abbruzzese G, Hardy JA. Substrateinduced conformational changes occur in all cleaved forms of caspase-6. J Mol Biol. 2011;406(1):75-91. doi: 10.1016/j.jmb.2010.11.031, PMID 21111746.

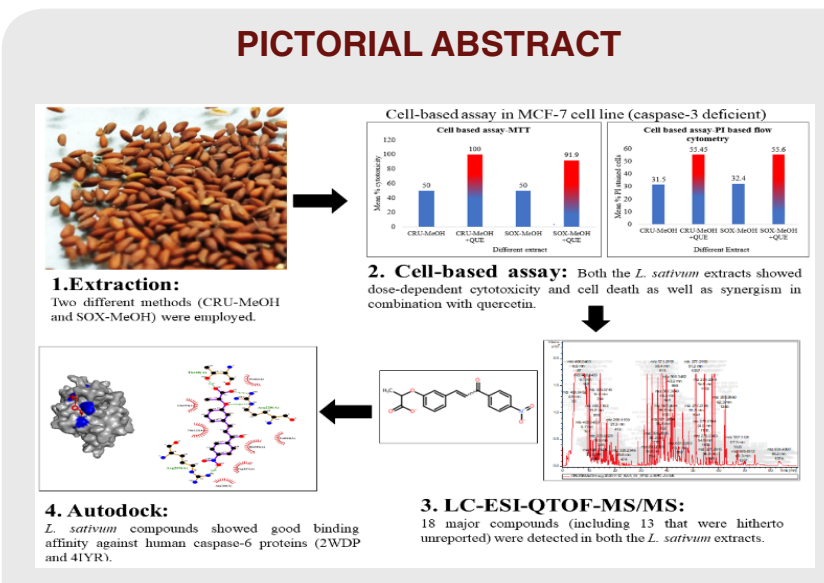

\section{SUMMARY}

Both extracts CRU-MeOH and SOX-MeOH showed a dose-dependent MTT-based cytotoxicity in the MCF-7 cell line (24h treatment period). Synergism was observed when the CRU-MeOH and SOX-MeOH were combined with quercetin. The LC-MS/MS showed the presence of bioactive compounds. Specifically, we have reported, for the first time, 13 compounds in our L. sativum seed extracts. Our preliminary docking-based in-silico analysis showed good binding affinity towards human caspase -6 when compared with that of quercetin -our reference molecule. 


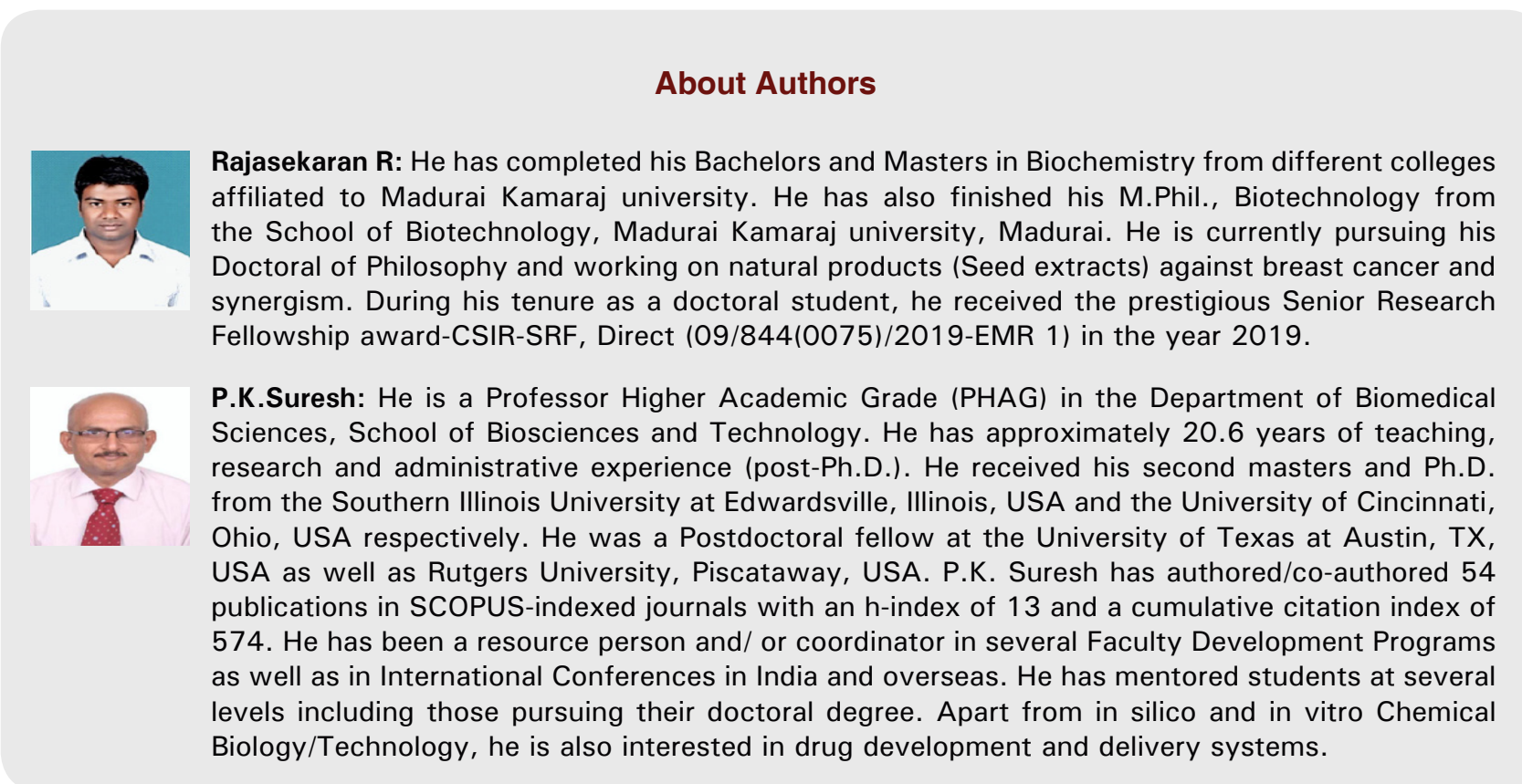

Cite this article: Rajasekaran R, Suresh PK. Evaluation of Cell Death Potential of Lepidium sativum Seed Extracts in MCF-7 Cells and Molecular Docking-based Correlation of Identified Bioactive Components with Human Caspase-6 Protein. Indian J of Pharmaceutical Education and Research. 2022;56(1):166-74. 